\title{
Biological, Psychological and Social Conditions Associated with Preterm Birth in Adolescents from Medellin, Colombia
}

\author{
Hernández J.D. ${ }^{1, *}$, Gómez R.D. ${ }^{2}$ \\ ${ }^{1}$ Public Health, Autonoma University of Manizales, Colombia \\ ${ }^{2}$ Public Health, University of Alicante, Spain \\ *Corresponding author: juandau_27@hotmail.com
}

\begin{abstract}
To establish the relationship between preterm birth and some biological, psychological and social conditions in pregnant women between the ages of 15 and 19. Materials and Methods: A non-matched case-control study was carried out on a random sample of postpartum adolescents' ages 15 to 19 years old from the metropolitan area of Medellin, Colombia, who received care in public and private hospitals in the city. A total of 126 postpartum adolescents with preterm birth and 114 controls with term birth were studied. The sample size was calculated based on the prevalence of family dysfunction, estimated at $15 \%$ for controls, with an OR (Odds Ratio) of 3.0, reliability of $95 \%$, an error of 0.05 and a power of $80 \%$. A semi-structured assisted and unbound interview that included family Apgar was applied to postpartum adolescents that agreed to participate in the study; additionally, the clinical record was reviewed. Results: The incidence of preterm birth was significantly associated with a greater exposure to family dysfunction during pregnancy ( $\mathrm{OR}=2.39 \mathrm{CI}$ (Confidence Interval) 95\% 1.10-5.20), economic pressures ( $\mathrm{OR}=2.43$ CI 95\% 1.16-5.10), as well as social pressures $(\mathrm{OR}=1.39 \mathrm{CI} 95 \% 1.07-1.813)$. The proportion of pregnant adolescents who considered themselves Caucasian was significantly higher in the group with term birth compared to other ethnic groups (OR $=0.219$ CI 95\%: 0.071-0.672). Recommendations: The findings suggest the importance of monitoring, evaluating and intervening with social support received by the pregnant adolescents from their partner as well as their social and family environment.The fact that most pregnant teenagers did not want their current pregnancy and considered it as an obstacle to their future endevours suggests the importance of defining policies and interventions to provide options that allow them to establish life plans according to their expectations.
\end{abstract}

Keywords: preterm birth, term birth, social determinants, psychosocial, teenager, bio-psycho-social, dysfunctional

Cite This Article: Hernández J.D., and Gómez R.D., "Biological, Psychological and Social Conditions Associated with Preterm Birth in Adolescents from Medellin, Colombia." American Journal of Public Health Research, vol. 5, no. 4 (2017): 105-114. doi: 10.12691/ajphr-5-4-3.

\section{Introduction}

Adolescence in women has been identified as an age of contradictions, misunderstandings and projections, where the discovery of personality in relation to others and expanding individual horizons in their psychosocial development becomes possible [1]. The definition and maturity of some psychosocial characteristics in the adolescent girl are strengthened at an older age, unlike the premature biological maturity at this formative stage, which has led adolescents to get into abortive fertility processes at early ages. Adolescent fertility is defined as: "The process that occurs within two years of gynecological age, that is understood as the time elapsed since menarche, and/or when the teenager is still dependent on their nuclear family of origin." [11]

A fertility process in adolescene can, directly or indirectly, affect the development of adolescent women in some social determinants such as the socioeconomic, psychosocial, and sociodemographic. This fact is alarming in relation to the global statistics, as one-third of 175 million pregnancies that occur annually are not desired. In turn, to identify that most of these cases correspond to adolescent women, teenage pregnancy becomes a fearsome state [1].

The article "Pregnancy and its Risks in Adolescence" states that more than $10 \%$ of births that occur annually worldwide correspond to young mothers, resulting in 15 million annual births to teenage mothers; 41,095 per day; and 1,712 per hour in Latin America.The countries with higher rates of adolescent maternity are in the regions of Nicaragua, Guatemala, Honduras, El Salvador and Venezuela. This represents between $15-25 \%$ of adolescents [1]. Another study reveals that the AFR(Adolescent Fertility Rate) has been declining since the 50's, but this fact is less marked than the GFR(General Fertility Rate), which determines an increase in the percentage of children of teenage mothers over the total births.The fertility rate was $11.2 \%$ in $1958 ; 13.3 \%$ in $1980 ; 14.2 \%$ in 1990 ; and $15 \%$ in 1993. This last percentage represents 120,000 live births from adolecense to the age of 20 [11]. 
In this regard, it is prudent to consider the adolescent pregnancy process in its progression, as a record of alterations, in order to observe the biological process, in which hypertensive disorders of pregnancy, poor weight gain, anemia, injury during childbirth secondary to cephalo-pelvic disproportion and preterm birth can be externalized more frequently. However, there are other social context variables that have been transgressed, such as dropping out of school, alterations in family processes, and changes in the performance of maternal-youth role [2,11,12].

Even though the biological context is one of the most important processes of gestation, we must understand that it is not the only one, since psychosocial bases have been evidenced in the development process of young women, demanding greater use of information, in order to investigate components that are part of the process of adolescence in matters of gestation. This fact, the misinformation, the lack of possibilities, as well as the sexual and reproductive development lead adolescents to consider themselves ready to conceive. Due to this, the teenage mother in this period is part of an important risk group regarding sexual and reproductive health, as they are exposed to early motherhood.

With regard to sexual and reproductive health, one of the goals in Colombia for 2015 was to reduce maternal mortality to 45 deaths per 1,000 live births. (38) The highest incidence rate is for higher fertility groups ages 20 to 29 . About $13 \%$ of maternal deaths occurs before the age of 20 , young women being the most affected population [6].

\subsection{Preterm Pregnancy in Adolescents}

Preterm birth is the leading cause of neonatal morbidity and mortality in Colombia and the world, identifying a variation in the frequency between $5 \%$ and $12 \%$ of births, where the risk of dying in a premature newborn is 180 times greater than the risk of a term newborn. Preterm infants who survive have an increased risk of sequelae and disability. [4] Despite technological and medical advances, as well as neonatal care, preterm birth continues to be the leading cause of neonatal morbidity and accounts for $70 \%$ of neonatal deaths and $50 \%$ of the neurological residual consequenes in the newborn [1].

The risk of dying during the first year of life is also higher for premature infants, as well as the probability of long-term sequelae such as: developmental delay, visual impairment, hearing deficits, chronic lung disease, and cerebral palsy. Proper management of pregnant women at risk of preterm birth can prolong intrauterine life, optimizing the conditions of the fetus [4].

\subsection{Intervention from Public Health}

Most of the developed, and Third World countries show a clear upward trend in the frequency of pregnant adolescents. This situation, in addition to the bio-psychosocial problems, deserves to be addressed as a special health problem where not only the mother-child is treated, but also the nuclear family, the school group, and even the community itself where the pregnant teenager interacts. All this with the particular interest of minimizing the risk involved in conception at an early biological and reproductive age [9].
The United Nations raised a global health strategy for 2015 and focused on the most affected groups, such as pregnant women and newborns. In this global strategy, it is said that the mortality of mothers and newborns has been significantly reduced in some countries [7]. On the other hand, a human development report done in 2003 shows that the millennium development goals, regarding the promotion of human development, have shared an ideal that reflects the commitment to promote the welfare of humanity, dignity, freedom, and equality for all people [5]. Some of its goals are:

To reduce infant mortality to less than 120 deaths per 1,000 live births for the year 2000 (World Summit for Children, 1990): Only 12 developing countries did not achieve this goal.

To reduce infant mortality by one-third during the 90's (World Summit for Children, 1990): 63 countries met this goal and more than 100 countries achieved a reduction of $20 \%$.

The evaluations of the Millennium Development Goals have shown that there is little reduction in the goals, mainly in 4 and 5, which should decrease at a rate of $6.3 \%$ and 5.5\% annually, to be completed in 2015 [7]. However, in Colombia infant mortality in children aged under five has significantly decreased, reaching figures close to 60 per 1,000 live births between 1975 and 1980, which is less than half between 1995 and 2000. Nevertheless, nowadays half of all deaths are related to perinatal conditions, infectious diseases, accidents and malnutrition [6].

Striving objectives have reflected an urgent need for a much faster development progress. The intention is to mobilize action and not to denounce or disgrace by demanding all players to identify new actions and resources to achieve those goals. It is also necessary to clarify that the poorer the country, the greater the challenge [5].

Despite the inequalities in Colombia, according to a 10 year public health plan, fertility has decreased from 91 births per 1,000 women to 74 between 1990 and 2010, showing that fertility in women ages 15 to 19 has presented an increase of almost 31\% between 1990 and 2005, although in 2010 it decreased to 84 births per 1,000 women. The behavior of adolescent fertility shows a predisposition to stabilize and even to continue a small rise, according to ENDSA 2010 (National Population and Health Surveys).

\subsection{Psychosocial Conditions}

Among the conditions affecting pregnancy, we found psychosocial aspects, observing prenatal effects as maternal stress, mediated by maternal neuroendocrine function, which may cause psychological distress in the fetus during pregnancy, associated with the hypothalamicpituitary axis, elevated cortisol and corticotropin releasing hormone, i.e, high norepinephrine and cardiovascular levels. Maternal distress such as: problems, depression and anxiety during pregnancy have adversely affected fetal development, which are the demographic characteristics and psychological disorders considered as potential risk factors for adolescent girls [12].

In particular, it has been observed that brain activity of newborns is a copy of the brain patterns of their mothers, 
presenting both brain activity in the right frontal area where negative emotions are processed. Blood pressure changes in pregnant women can alter the normal functioning of the endocrine system, which generates a hyperactive state in the thyroid and adrenal glands. Secretions from these glands are directed to the fetus, which increases the heart rate.Uterine development as described previously does not help the adaptation of the newborn to their postnatal life [13].

Stress during pregnancy causes in the newborn hyperactivity, irritability, sleeping disorders and irregular eating patterns, excessive movements in the intestines, persistent crying, low birth weight, as well as a high need to be in arms [13]. A prospective study on psychosocial predictors of low birth weight identified that birth weight, gestational age and neurological conditions of children in the neonatal period are measures that allow for the evaluation of perinatal outcomes associated with different indicators such as: smoking, low income, unemployment, low family functioning, exposure to life events, family stress and high workload [14]. These factors have been associated with an increased risk of low birth weight for the gestational age. The study also indicated that psychosocial factors in pregnancy contributes to low birth weight for gestational age, regardless of the number of cigarettes smoked per day, the educational level, maternal height and weight. This study focused its interest on demonstrating that psychosocial factors in the first quarter have a negative effect on weight. Daily stress factors in this same period seem to be an important psychosocial risk factor.

The psychological aspects that can occur in pregnant women are phenomena that are generated directly or in a pathophysiological way by the state of pregnancy, such as: memory and mental disorders (situational reactions); however, there are other peripheral noxas of psychogenic origin that can alter the emotional and personal stability of the pregnant woman, becoming triggering events of prematurity. Some of them are:

- Non-transitory family crisis.

- Marital maladjustment.

- Alterations between interpersonal relationships.

- Inadequate family situations.

- Difficulties in social and economic dynamics [15]

Adolecent women who become pregnant in an under developed biological environment feel limited by their unexpected pregnancy, and can experience the social stigmitization of becoming single mothers. This in turn, leads them to exhibit inappropriate behavior and avoidance of those who are not facing this situation yet [15].

Pregnancy becomes a difficulty that incapacitates the crisis of adolescence by somatic and psychosocial changes with increased emotivity and accentuation of unresolved conflicts. Since the pregnancy is unplanned, incomparable attitudes can be adopted depending on the following factors: personal stories, family, and social context. In general, it can be said that maternity is estimated as a development crisis that has difficult aspects, but it also has advantages that contribute to the psychological and social growth of the mother. In Colombia, teenage pregnancy was considered by the National Academy of Medicine as a serious public health issue and a sign of underdevelopment [12]. This institution also reported on the percentage of young people with higher education who were already mothers between
2000 and 2005; it increased from 2.3\% to 7.4\%, which clearly affects their life projects [12].

In the study "Characteristics of Psychosocial and Health of Pregnant Women who want or do not want their Pregnancy," almost $50 \%$ of the total sample rejected the pregnancy. $67 \%$ of this percentage felt "a lot" of discomfort at being pregnant. Due to the high percentage of women who expressed rejection to their pregnancy, the behavior of the characteristics already indicated in women who wanted their pregnancy and those who rejected it were analyzed [13]. With regard to the results of the demographic and healthsurveys in Colombia, the proportion of adolescent and pregnant mothers has increased considerably between 1990 and 2010, increasing from $12.8 \%$ to $19.5 \%$; however, the last five years show a slight downward trend.

\subsection{Sociodemographic Conditions}

Maternal sociodemographic characteristics also significantly represent $26 \%$ of the variance in maternal psychological distress regarding the close relationship between psychosocial variables (daily discomfort, anxiety, and depression scores). These were significantly related [18]. In the case of Colombia, it has been found that among adolescents, exposure to risk of pregnancy, use of birth control methods and induced abortion have been increasing, while the role of the married couples and couples living together has been passive, according to Florez and Nuñez (2003). This process has been accompanied by a significant decrease in the age of onset of sexual intercourse [19].

In different studies conducted in Colombia, the factors that have been associated with teen pregnancy have been examined. The findings of this research indicate that the likelihood of teen pregnancy is associated with individual personal factors, such as: level of education, access to SRH (sexual reproductive health) information and contraceptive methods. In addition, perceptions of social norms, motherhood, as well as opportunities for social mobility play a role in the pregnancy. Additional aspects include interpersonal factors such as household socioeconomic status, family structure, family violence, communication with parental figures, parental supervision, and attitudes of peers toward sex in adolescence and contextual factors such as level of urbanization, and supply of SRH quality services, among others [16].

The negative results regarding demographic issues cause extreme poverty in families, as an increase in the volume of family and number of children presents short and longterm effects on the family welfare. This fact reduces the labor participation of parents, and therefore, the household income. On the other hand, the investment of human capital of the children can decrease, due to the reduction in funds in health and education, losing potential opportunities for children, and of course, for teenagers [17].

In Colombia, adolescent fertility is five times higher among quintile 1 and 5 (40\% vs. 8\%). This is explained by the time of exposure to higher marriage rates and higher unmet needs for family planning. Additionally, according to Florez and Nuñez (2002), other findings indicate that reducing household size has a positive effect on poverty reduction [17]. 
Until now, the studies on adolescent fertility in Colombia have been focused on analyzing its determinants, without considering in the estimates, the problem of making a decision to become a teenage mother and the variable to study. The link between the phenomenon of fertility and well-being of adolescent mothers and their children has not been completely addressed either [17].

\subsection{Socioeconomic Conditions}

It has been known that poverty is a phenomenon caused by multiple components, which shows the existence of the link between demography and individuals' quality of life. On a wider level, the relationship between these two phenomena may be caused by different conditions; however, it can be said that poverty and demography are related through economic growth and income distribution, which are reduced to the extent that the number of inhabitants increases. This indicates that, in some way, there is a recommended population size that minimizes the poverty level [17].

Out of the 4.5 percentage points of reduction of poverty in the period from 1991 to 1995, 2.1are explained by changes in household size; nevertheless, the recovery of poverty rates, following the crisis of the nineties is explained by $60 \%$ and $17 \%$, due to the reduction in household size in urban and rural areas of Colombia [20].

In a study conducted in Venezuela on socioeconomic status and nutrition in pregnant women, it is said that life generated in the mother's womb involves genetic factors, maternal and environmental conditions, as well as the energetic material consumed. In Latin American countries, the foreign debt and conditions of resource management have led to a deplorable socioeconomic status and have impacted the quality of life, health, nutrition and poverty [21].

However, an epidemiological profile in Valencia (Spain), showed that the incidence of preterm birth is influenced by socioeconomic factors, especially in young populations, which shows the social differences represented by levels of maternal education and household income. It was found that the preterm birth at 32 weeks was higher in women who interrupted their studies before the age of 15 (OR: 1.19: CI 95\% 1.07-2.98), aged 35 years and older (OR: 2.53: CI 95\% 1.42 -4.52) and multiparous with threatened abortion in the first trimester (OR: 1.86: CI 95\% 1.13-3.04) [22].

In a national context, there is a study carried out at the National University that identifies some related studies in Colombia, which showed an increased risk in pregnant adolescents for preterm birth $(\mathrm{RR}=4.7)(24)$. Also, in Bogotá, a study on nulliparous women aged between 10 and 29 years, served between September 1, 1998 and December 31, 1999 ( $n=8.045)$ was conducted taking into account the database from the Perinatal Network of the Ministry of Health of Bogota. It was found that newborns of adolescents under the age of 15 have significantly higher risk of prematurity (RR or Relative Risk 1.88; CI 95\% 1.14 - 3.11), low birth weight (RR 1.61; CI 95\% 1.12 - 2.32) and being small for gestational age (RR 2.09, CI $95 \% 1.24$ - 3.52) compared with newborns of mothers between the ages of 15 and 29. This shows that our reality is not far from the others' reality, which goes into the same lineament information [23].
In the Latin American context, important figures that categorize developing countries, including Colombia, in social scourge are reported. It was found that in Ecuador, between 2003 and 2008, the proportion of pregnancy in women ages 15 to 19 years old increased from $14.7 \%$ to $18 \%$, where more than $25 \%$ of teenage mothers have only completed primary education. In Colombia, the percentage of teenage mothers was $17.4 \%$ for 1995 , rising to $20 \%$ for 2000. This fact has impacted the education, employment and professional development of adolescents, who do not fully develop within a socioeconomic context [25].

It can be concluded that: the characteristics of the conditions that trigger preterm birth are multifactorial, whether in a social, emotional, nutritional, infection and anatomical deprivation context, or in a hereditary context, where intervention should always be timely [26]. It is then possible to establish prematurity as a state that is related to different socioeconomic, psychosocial, demographic and biological factors that influence the term birth.

\section{Materials and Methods}

This was a case-control study without comparing puerperal adolescents who gave birth to pre-term infants and adolescents who gave birth to term infants. The former being the cases and the latter the controls.

Cases and controls were selected among puerperal women who received care and registered in obstetricsgynecology services in the city of Medellin, Colombia.

The sample was observed regarding all the incident cases of preterm births of the adolescents who went to the doctor during pregnancy (adolescent mothers between the ages of 15 and 19 years old). Controls were incident cases of term births of teenagers. It is important to note that the sample was randomly selected and not matched in the same institution and treated at a date close to the cases. The determination of the sample was based on the prevalence of psychosocial dysfunction, based on family Apgar as a determinant independent variable [70].

Each of the psychosocial exposures in the subjects of interest can have their own dynamics and its particular association with preterm birth. It is highlighted that with respect to these associations there are no previous studies within the area being studied. In order to estimate the sample size, it was assumed that at least $30 \%$ of cases may have been exposed to psychosocial deprivation during pregnancy and that this condition could have also occurred in about $10 \%$ of controls for exposure ratio of 3.0. The sample size was calculated based on a power of $80 \%$, a margin of error of $5 \%$ and a confidence of $95 \%$. Based on this criteria, the sample size was estimated at 101 cases and 101 controls. An oversampling was added to minimize missing data. At the end of the period, an informed consent was signed by the 126 pregnant women with preterm and 114 term delivery [69].

\section{Results}

The following are the main univariate and bivariate results regarding socio-demographic variables. 
As expected, due to the methodological design, gestational age was significantly lower $(\mathrm{t}=19.556$, $0=0.000$ ) among pregnant adolescents with preterm birth ( $\bar{X}=34.18 \pm 2.49$ ) compared to the other group. $(\bar{X}=39.12 \pm 1.09)$. A similar difference was found in relation to the weight of the mother in the last month of pregnancy. It was significantly lower $(\mathrm{t}=0,286,0=0,006)$ among pregnant women with preterm delivery ( $\overline{\mathrm{X}}=62.14$ \pm 15.4 kg.) in comparison with the other group. ( $\bar{X}=67.02 \pm 11.2 \mathrm{~kg}$.). The newborn weight was significantly lower $(\mathrm{t}=10.84,0=0.000)$ among pregnant women with preterm birth $(\bar{X}=2364 g m . \pm 636)$ than among the other group ( $\bar{X}=3187$ gm. \pm 526$)$. Weight in early pregnancy was $51.8 \pm 15.5 \mathrm{~kg}$. in both groups without differences associated with preterm delivery $(\mathrm{t}=0.573,0=0.567)$.

Most pregnant adolescents came from Medellin, with a similar distribution: $78 \%$ of those pregnant with preterm birth, and $80 \%$ with term birth.

$60 \%$ of pregnant teenagers was affiliated to the subsidized health system with no association between the health scheme and the preterm delivery $(\mathrm{OR}=0.725$, CI95\%: 0.431 to 1.219 ).

$11.6 \%$ of the adolescents was already affiliated to the social security system as a taxpayer, one had no information, and the rest had the status of beneficiary. The background to contribute directly to social security, which means they have paid employment, was significantly more frequent among those who had preterm delivery $(\mathrm{OR}=$ 2.500; CI95\%: 1.054 to 5.925).

Most of the participating adolescent mothers identified themselves as mestizo. Women who identified themselves as Caucasian had a lower frequency of preterm birth compared to those of other ethnic groups. This difference was statistically significant, and also according to the value of OR that behaves as a protective factor $(\mathrm{OR}=$ 0.360; CI95\%.142-.911). Among the other groups, the ratio of preterm births was not statistically significant.

With regard to the socioeconomic status of the neighborhood of origin, most pregnant adolescents (97.5\%) came from areas of low and medium strata such as strata 1 to 3 (considered as low income households); no association was found between lower strata and preterm delivery. (OR = 1.108, CI95\%: 0.219 to 5.603).

Despite being young women, most of them had more than five children, this could be correlated with the highest source of lower strata neighborhoods. No association was found between a history of having 3 or more children and the preterm delivery. (OR =1.166; IC95\%:0.686-1.984)

$23.3 \%$ of pregnant adolescents reported having been exposed to economic constraints during pregnancy. This fact was significantly higher among adolescents who had preterm delivery (OR = 3.183, CI95\%:1.647 to 6.151).

$10.8 \%$ of pregnant adolescents reported having been exposed to social pressure during pregnancy. This fact was significantly higher among adolescents who had preterm delivery, being a risk factor (OR = 8,262; CI95\%: 2.408 to 28.342 ).

$18.8 \%$ of pregnant adolescents reported having been exposed to a kind of social rejection during pregnancy. This fact was not associated statistically with preterm birth (OR = 1.300; CI95\%: 0.675 to 2.502).
$69.2 \%$ of pregnant teenagers did not seek this pregnancy. This was not associated with differences in the occurrence of preterm delivery (OR $=1.462$, CI95\%: 0.843 to 2.535$)$.

$22.8 \%$ reported that during pregnancy they had no support from their partner. This condition was significantly more frequent among those with preterm birth, being a risk factor for premature delivery (OR = 2.282, CI95\%: 1.198 to 4.346).

$17.9 \%$ reported some type of family pressure during pregnancy. This fact was significantly more common among pregnant women with preterm delivery, being a risk factor for premature delivery $(\mathrm{OR}=2.135$, CI95\%:1.063 to 4.284 ).

9.58\% experienced some type of academic pressure during pregnancy. This condition was significantly more common among pregnant adolescents with preterm delivery (OR = 2.807, CI95\%: 1.066 to 7.390$)$.

$31.25 \%$ expressed that being a teenage mother had closed doors in their lives. The frequency of this among pregnant adolescents is important; however, it was not statistically associated with preterm delivery. $(\mathrm{OR}=$ 1.059,CI95\%:0.699 to 1.604).

Eight of the interviewed adolescents (3.33\%) experienced a feeling of indifference when receiving the newborn. They all belonged to the group being studied. For this analysis, no significance tests were applied because ratios were zero.

$10.83 \%$ of adolescents denied having felt joy at receiving the newborn. This condition was greater among adolescents with preterm birth, being a risk factor for premature termination of pregnancy (OR $=2.71$; CI95\%: 1.09 to 6.72 ). However, the study does not clarify whether this relation is due to the gestational process or condition of the newborn. When analyzing the functionality of the family circle according to the Apgar score, it was found that most pregnant adolescents had a normal-functional family; $18.8 \%$ belonged to mild dysfunctional families and $1.2 \%$ severely dysfunctional families. Belonging to families with some degree of dysfunction was significantly more common among pregnant adolescents with preterm birth being a risk factor for preterm birth $(\mathrm{OR}=3.400,95 \% \mathrm{CI}$ : 1.668 to 6.930$)$. This association remained when mild dysfunction was analyzed separately; compared to the families who seemed to be functioning normally; mild dysfunction was also significantly more common among pregnant women with preterm delivery (OR = 3.966, CI95\%:.859- 8.463).

With regard to the age of the mothers, it was observed that $25 \%$ were 18 years old, in turn it was identified that only 2 out of 10 cases met the same age. For $46 \%$ of cases and controls, adolescent mothers were already 19 years old, only an approximation of $2 / 10$ of the sample was underage mothers younger than 17 years old.

The review of morbid history during gestational age recorded in the medical history, such as heart, kidney, hypertension or preeclampsia problems among others, were not associated with significant differences against preterm delivery.

$3.75 \%$ of pregnant adolescents presented cardiac alterations during pregnancy. No statistical association was found between this medical history and the preterm birth (OR = 7.66; CI95\%: 0.943 to 62.239). 
Table 1. Variables included in the model

\begin{tabular}{|c|c|c|c|c|c|c|c|c|}
\hline & \multirow{2}{*}{ B } & \multirow{2}{*}{ Standard error } & \multirow{2}{*}{ Wald } & \multirow{2}{*}{ gl } & \multirow{2}{*}{ Sig. } & \multirow{2}{*}{$\operatorname{Exp}(B)$} & \multicolumn{2}{|c|}{ 95\% CI for exp (B) } \\
\hline & & & & & & & Inferior & Advanced \\
\hline Mild or severe family dysfunction & .873 & .396 & 4.857 & 1 & .028 & 2.394 & 1.101 & 5,203 \\
\hline Economic pressure & .890 & .378 & 5.562 & 1 & .018 & 2.436 & 1.162 & 5.105 \\
\hline Social pressure & .331 & .135 & 6.055 & 1 & .014 & 1.393 & 1.070 & 1.813 \\
\hline family pressure & .036 & .104 & .123 & 1 & .726 & 1.037 & .847 & 1.270 \\
\hline academic pressure & .225 & .188 & 1.424 & 1 & .233 & 1.252 & .866 & 1.810 \\
\hline Partner support & -.404 & .366 & 1.220 & 1 & .269 & .668 & .326 & 1.368 \\
\hline Belonging to different ethnicity to Caucasian & -1.520 & .573 & 7.046 & 1 & .008 & .219 & .071 & .672 \\
\hline Constant & -.886 & .599 & $2, .87$ & 1 & .139 & .412 & & \\
\hline
\end{tabular}

Table 2. Bivariate and multivariate association between some social conditions and preterm delivery in adolescents, Medellin 2014

\begin{tabular}{|c|c|c|c|c|c|}
\hline \multirow{2}{*}{ Association with preterm birth } & \multicolumn{2}{|c|}{ Bivariate analysis } & \multicolumn{3}{|c|}{ Logistic regression } \\
\hline & OR Bivariate & CI 95\% & Adjusted OR & Lower limit & Upper limit \\
\hline Family dysfunction (mild or severe) & $3.40^{*}$ & $1.668-6.930$ & 2.394 & 1.101 & 5.203 \\
\hline Exposure to economic pressures & $3.18 *$ & $1.647-6.151$ & 2.436 & 1.162 & 5.105 \\
\hline Exposure to such social pressures & $8.26 *$ & $2.408-28.342$ & 1.393 & 1.070 & 1.813 \\
\hline Exposure to family-type pressures & $2.13^{*}$ & $1.063-4.284$ & 1.037 & .847 & 1.270 \\
\hline Academic pressures exposures type & $2.80 *$ & $1.066-7.390$ & 1.252 & .866 & 1.810 \\
\hline Lack of support from the couple & $2.28 *$ & $1.198-4.346$ & .668 & .326 & 1.368 \\
\hline Self-perception of being Caucasian & $0.360 *$ & $0.142-0.911$ & .219 & .071 & .672 \\
\hline
\end{tabular}

\subsection{Multivariate Analysis}

A multivariate logistic regression by the method "enter" was performed with the variables that were statistically associated with preterm birth in the bivariate analysis. The following model was tested with the Wald Statistics and the association of preterm birth with economic constraints, social pressure, self-perception of belonging to white ethnicity and family dysfunction persisted after adjustment. However, the significance of the associations between preterm birth with the support of the partner and academic, as well as family pressures disappeared.

\section{Discussion}

Maternal age ranged between 15 and 19 years $(\bar{X}=17.9$ \pm 1.2 ) no differences between cases and controls ( $t=-0.298$, $0=0.766$ ) were found. All pregnant adolescents came from Medellin; origin did not show association with term delivery. Most pregnant adolescents considered themselves mestizo. 9.6\% of Caucasians showed a significantly lower risk of preterm bird compared to the rest of the sample.

Most of the pregnant adolescent belonged to lower strata neighborhoods. This condition was not associated with preterm birth. According to Hoffman (1995), social class has somehow been established due to the father's occupation, thereby affecting belief, values and lifestyles systems. This in turn creates one of the macro systems that affects development. Hoffman also stated that social class helps determine the physical environment where the newborn will live, with this in mind it could be stated that the environment where newborns will be, is perhaps the same one that the teenage mother had during her gestational process [36]. The socioeconomic variable would not only impact on the living conditions of families, but it could also be a factor influencing the gestational process that the adolescent mother lives in relation to some socio-emotional conditions. McLoyd (1989) states that children whose parents are unemployed for a long time can manifest certain socio-emotional problems, such as being depressed, feeling alone, feeling excluded from their peers, as well as showing low self-esteem and low ability to cope with stress. This is relevant because mothers between the ages of 15 to 19 years old may be influenced by a factor such as unemployment, particularly, if they are financially dependent on their parents.

Although the Quality of Life Survey (2010) suggests that $37.13 \%$ of the population of Medellin belonged to the subsidized regime or to a poor population with no regime [35], $11.6 \%$ of pregnant adolescents were affiliated to the contributory health system which means they have paid employment. This fact was significantly more frequent among those who had preterm birth.

Associating economic variability with responsibilities obtained by an adolescent mother, the young mother will be forced to seek income required to cover the future needs of her child, mainly if she already has a dependent child, as was stated by $59 \%$ of the mothers who had a preterm birth. This as an emotional pressure could push the mother to make drastic decisions such as academic desertion, in order to search for income. In this regard, the Medellin ombudsman has shown that the dropout rate was close to $4.4 \%$ for 2013 , also showing that one of the main causes of this phenomenon was the lack of institutional provision, the economic situation of families and students that are led to leave their studies and start working (primarily in the districts 8, 13, 9, 16 and the districts of AltaVista and San Antonio de Prado). [35] Among pregnant adolescents, the approved number of school years ranged between 2 and $11(\bar{X}=9.3 \pm 2.0)$, no differences between cases and controls $(\mathrm{t}=-0.255,0=0.799)$ were found. $6.7 \%$ of pregnant adolescents had not studied beyond primary without statistical association of this condition with preterm birth. Meanwhile, $42.9 \%$ of pregnant adolescents attended some form of study during 
pregnancy, this condition was not associated with preterm birth.

Despite being young girls, most pregnant women had more than two dependent children $(\bar{X}=2.82 \pm 1.78)$, which could be correlated with the greatest source of lower strata neighborhoods. However, no statistical association between the history of having 3 or more children and preterm birth ( $\mathrm{t}=-0.982,0=0.327)$ was found. No statistically significant association between the number of dependent people and preterm birth $(\mathrm{t}=0.736$, $0=0.462, \bar{X}=3.32 \pm 0.69$ ) was found. Almost a quarter of the pregnant adolescents had done some form of work activity during pregnancy; 3.32 daily hours on average \pm 0.69 ; but this activity was not associated statistically with preterm birth. The vast majority of pregnant adolescents (76.3\%) reported carrying out domestic chores during pregnancy. This activity was not related to the presence of preterm birth either. A fifth of pregnant adolescents practiced a sport during pregnancy and this activity was not related to preterm birth.

With regard to the diversity of activities that an adolescent mother can develop, some fluctuations within the possibilities have been found. A limitation related to the number of dependents, marking differences between the possibilities of the father and the adolescent mother and their obligations, without taking into account that they are already mothers and have previous responsibilities. Madrid (2005) expresses how the discrepancy between activities are mediated by the status as a parent. Adolescent fathers could work at a rate almost three times higher than adolescent mothers. However, $50 \%$ of women who were mothers before age 20 do not do paid work, the opposite of fathers. This allows us to infer that responsibility within the family grows more for the young mother than for the father. Madrid also teaches that the distribution of paid and unpaid work is clearly divided into gender, showing even greater force in the asymmetry for the group that has had children in adolescence [72].

In relation to stressors during pregnancy almost a quarter $(23.3 \%)$ of pregnant adolescents reported having been exposed to an economic pressure during pregnancy and this was significantly higher among adolescents with preterm birth. 9.58\% of the adolescents experienced some type of academic pressure during pregnancy and this condition was significantly more common among pregnant adolescent with preterm birth.

Alfredo J. (2005) has described "stress in adolescents" as the process of adolescence and it has been identified as a special stage of stress, where there are many psychological, physical and social influences on youngsters in their developmental stage. Alfredo J. also relates a list of possible typical adolescent stressors such as hormonal changes, pubertal growth, genetic vulnerability to disease, increased sexuality, changes in independence and dependence related to parents. Additionaly, new cognitive skills development, changes in the relationship of parents towards adolescents, cultural and social expectations of adolescents, gender roles, pressure from other teenagers, parental psychopathology, changes at school, family moves, decreased marital harmony between parents and divorce, meetings with the authorities, sexual abuse, and others. Among the pressures expressed by adolescents, commom stressors are similar.
This along with the pressure of being a mother could significantly increase the risk of preterm birth due to the lack of ability for catharsis of certain situational factors [73].

It has been reported that the presence and quality of emotional relationships have a significant impact on the child's physical and psychological well-being, literature states that the mother's emotional condition affects the fetus [13]. In this study, more than one fifth (22.8\%) of pregnant adolescents reported that during pregnancy they had no support from their partner and this condition was significantly more frequent among those with preterm birth. The problem is not only the lack of support but rejection. $10.8 \%$ of pregnant adolescents reported having been exposed to a social pressure during pregnancy and this was significantly higher among adolescents with preterm birth. $17.9 \%$ of pregnant adolescents reported some type of family pressure during pregnancy and this was significantly more common among pregnant women with preterm labor. $18.8 \%$ of pregnant adolescents reported having been exposed to some form of social rejection during pregnancy, although, this condition was not statistically associated with preterm birth.

A particularly important finding of this study concerns the relationship between family dysfunction and preterm birth. The dysfunctionality, which is an indicator of the mental health of a population, was evident in almost a fifth of the families of the pregnant adolescents and was associated with a higher incidence of preterm birth.

The vast majority (69.2\%) of pregnant adolescents of this study did not seek this pregnancy and this was not associated with differences in the occurrence of preterm birth. $10.83 \%$ of adolescents denied having felt joy at receiving the newborn; although this finding was greater among adolescents with preterm birth. This study does not clarify whether this relationship reflects the gestational process or the condition of the newborn. A high proportion of pregnant adolescents (68.8\%) showed that being an adolescent mother had closed doors in their lives. Although this condition is worrying, it was not statistically associated with preterm birth.

With regard to the above mentioned, there are factors that could overcome to a great extent the adolescent desire to become a mother. This fact in the light of pregnancy would become a difficulty surpassing the adolescent crisis due to somatic and psychosocial changes with an increase in emotional aspects and accentuation of unsolved conflicts, as discussed by Estupiñan (2009). He also refers to the fact that somehow the young woman could adopt incomparable attitudes that depend on: personal stories, family and social context. The authors define motherhood as a developmental crisis with difficult traits, as well as advantages that support psychological and social growth. However, it should be noted that the National Academy of Medicine in Colombia considers pregnancy mainly in adolescents as a serious problem in public health and a marker of underdevelopment [37].

When analyzing the functionality of the nuclear family according to the family Apgar test score most pregnant adolescents had a normal-functioning family; $18.8 \%$ belonged to mild dysfunctional families and $1.2 \%$ severely dysfunctional families. Belonging to families with some degree of dysfunction was significantly more common among pregnant women with preterm birth. This 
association remained when mild dysfunction was analyzed separately; compared to normotensive pregnant adolescents whose families seemed functional, mild dysfunction was also significantly more common among pregnant women with preterm birth.

Regarding the psycho-emotional fluctuations of adolescents and their nuclear families, the manifestation of rejection may be an important fact in the unresolved conflicts that pregnant adolescents can go through. A mother with mild or severe dysfunction in her nuclear family could find refuge in different people as her partner, and the fact that getting pregnant and not receiving the support from her partner could influence the preterm birth. This added to the belief that pregnancy can close doors in her life, it becomes a process that requires immediate intervention. Its significance lies in the presence or absence of nearby people [13].

The nuclear family should meet the basic needs of its members as far as it is possible, and it becomes the means to transfer cultural and moral values as well as, customs and traditions to new generations. As stated by Rangel, L. (2005), highlighting that the arising adolescent pregnancy in the nuclear family forces a restructuration of the occupations of their members by creating new needs regarding this new process and by requiring adaptation to the system to find a new state of family homeostasis that initially it may be rejected, creates surprise and frustration for everyone. This environment could be somehow influencing the development of the gestational process.

Finally, as expected due to the methodological design, the weeks of gestation, the weight in the last month of gestation and newborn weight were significantly lower among pregnant adolescents with preterm birth compared to adolescents with term birth. In both groups, early pregnancy weight was similar (51.8 $\pm 15.5 \mathrm{~kg}$.).

\section{Conclusions}

Among the pregnant adolescents studied, prevailing factors were low socioeconomic status, low educational level, and origin of low-income areas of the city. However, these conditions were not statistically associated with preterm birth.

In the bivariate analysis, preterm birth was statistically associated with the lack of support from the partner and with family and academic pressures, although, these associations disappeared in the multivariate adjustment. Instead, exposure to family dysfunction, self-perception of belonging to the Caucasian race and economic, as well as social pressures during pregnancy maintained their association with preterm birth after adjustment. These findings highlight the importance of social conditions in the development of adolescent pregnancy and suggest the value of assuring adequate social support during this period which must begin with the support from the partner and extended to the family and social nucleus.

The vast majority of pregnant adolescents of this study did not seek this pregnancy, although this fact was not associated with differences in the occurrence of preterm birth. In addition, a high proportion of pregnant adolescents expressed that motherhood had closed doors in their lives. Although these conditions were not statistically associated with preterm birth, the prevalences are worrying and suggest the need to strengthen preventive measures.

\section{Suggestions}

The findings suggest the importance of assessing and intervening social support received by their partners and their family and social environment as well.

The evaluation of economic and social pressures and family dysfunctionality as well, should be part of the surveillance during the gestational process in adolescents.

The fact that pregnant adolescents have not desired to get pregnant and that they consider it an obstacle to their future lead to thinking about the importance of establishing policies and interventions to provide options for adolescents and allow them to project their lives according to their expectations.

Similarly, the frequency of family dysfunctionality in the population and its association with preterm birth that remains after adjustment, it has been suggested that it is of importance to evaluate and control this variable during pregnancy and expand the knowledge about other mental health conditions that could affect pregnancy as well.

\section{References}

[1] Sáez Y G, Sáez I H, Martín M C, et al. El embarazo y sus riesgos en la adolescencia. Archivo Médico de Camagüey, 2014, 14(1).

[2] Noguera N, Alvarado H. Embarazo en adolescentes: una mirada desde el cuidado de la enfermería. Revista Colombiana de Enfermería. Vol. 7. P.151-160. P. 152.

[3] Ministerio De Salud. Guía Clínica Prevención Del Parto Prematuro: 1st Ed. Santiago. Ministerio De Salud: 2005.

[4] Estrategia UNICEF, para contribuir a la reducción de la morbimortalidad materna, neonatal e infantil. Salud nutrición informe. 2011-2015.

[5] Los objetivos de desarrollo del Milenio: informe sobre desarrollo humano. PNUD. 2003.

[6] Informe de Desarrollo Humano. Estado de los objetivos del milenio en Colombia. Bogotá: Mundi prensa. 2003; 187.

[7] Ministerio de la Protección Social. Instituto Colombiano de Bienestar Familiar. Profamilia. Encuesta Nacional de Demografía y Salud: Colombia-ENDS. (2011).

[8] Proyecto de ley. Por la cual se protege la maternidad, el parto digno y se dictan otras disposiciones. 060 de 2007 senado. Bogotá; 2007.

[9] López Canales J R, Vallecillo Molina G, Funez T L, et al. Consideraciones biologicas en la gestante adolescente. Rev. latinoam. perinatol, 1986, 6(4): 115-22.

[10] Hernández Upegui J D. Condiciones biológicas, psicológicas y sociales asociadas con el parto pre término en gestantes adolescentes atendidas en Medellín entre 2013 y 2014. 2017.

[11] Issler J. Embarazo en la adolescencia. Revista de Posgrado de la Cátedra VI Medicina. 2001; N 107: 11-23.

[12] María R, Estupiñan A. Aspectos psicosociales en universitarias embarazadas, Revista salud pública. 2009; 11 (6): 988-998.

[13] Rojas J. Características Psicosociales y de Salud de Gestantes que desean o no su embarazo, Revista Comportamiento. 2005; Vol 7 (2) 0798-1341.

[14] Paarlberg KM, Vingerhoets JM, Passchier J, Dekker GA, Heinen AG, et al. Psychosocialpredictors of lowbirthweight: a prospectivestudy. BJOG 1999; 106: 834-841.

[15] Camejo R, Marrero D. Factores Psicosociales que influyen en el riesgo de prematuridad en un área de salud. Policlínico Gustavo Aldereguía. Facultad de ciencias médicas. 2006.

[16] Florez C. Factores protectores y de riesgo del embarazo adolescente en Colombia, serie de estudios a profundidad. ENDS; 1990: 2010. 
[17] Miguel A, Nancy A. Maternal Psychological Distress, Prenatal Cortisol, and Fetal Weight. Psychosomatic Medicine. 2006; 68: 747-753.

[18] Flórez C E, Soto V. Salud sexual y reproductiva de las adolescentes. Fondo de Población de las Naciones Unidas. Bogotá, 2006.

[19] Méndez J A N, Rueda L A C. Efectos demográficos sobre el bienestar de las madres y sus hijos en Colombia. Departamento Nacional de Planeación, 2007.

[20] Méndez J N, Ramírez J C, Cuesta L. Determinantes de la pobreza en Colombia, 1996-2004. United Nations Publications, 2006.

[21] Faneite P, Rivera C, González M, et al. Estudio socioeconómico y alimentación en las embarazadas: análisis médico integral. Rev. obstet. ginecol. Venezuela, 2003, 63(1): 3-10.

[22] Escriba V, Clemente I. Factores socioeconómicos asociados al parto pretérmino. Escuela Valenciana de Estudios para la Salud. Gac Sanit. 2001; 15 (1): 6-13.

[23] Villanueva A, Contreras A. Perfil epidemiológico del parto prematuro, GinmecolObstetMex 2008;76 (9): 542-8.

[24] de Rivas Y Q, Bastardo G, Angarita C, et al. Consumo de alimentos, factores socioeconómicos y anemia en mujeres gestantes. An Venez Nutr, 2012, 25: 64-72.

[25] Pacora P, Buzzio Y. El peso del recién nacido sano según edad gestacional en una población de Lima. An Fac Med Lima 2005; 66. (2). p. 212-217.

[26] World Health Organization (WHO). Organización Mundial de la Salud (OMS). Emergency Contraception, A Guide For Service Delivery, 2012: 7.

[27] Langer A. El embarazo no deseado: Impacto sobre la salud y la sociedad en América Latina y el Caribe. Revista Panamericana Salud Públican. 2002; 11(3).

[28] Espinoza J. Simposio Fisiopatología del síndrome de parto pre término Rev Per Ginecol Obstet. 2008; 54: 15-21

[29] Palencia A. Parto prematuro. Sociedad Colombiana de Pediatría. [Internet] Disponible en: https://scp.com.

co/precop/precop_files/modulo_9_vin 4/Precop_9-4-B.pdf (Consultado: 15 de septiembre de 2015), 2009.

[30] Morales R, Vega A J. Factores de riesgo materno asociados al parto pretérmino. Rev Med IMSS, 2005, 43(4): 339-342.

[31] Morgan F, Gomez Y. Factores sociodemográficos y obstétricos con rotura prematura de membranas. Ginecol Obstet Mex. 2008; 76 (8): 468-75.

[32] Sarmiento G. Importancia de los antecedentes maternos en el recién nacido bajo peso. Rev Cubana Med Gen Integr 2000; 16(5): 502-7.

[33] Martínez G, Pérez D. Repercusión biológica, psíquica y social del embarazo en la adolescencia. Revista Cubana Enfermería. 2002; 18 (3): 175-83.

[34] Bonilla-Sepúlveda Ó A. Depresión y factores asociados en mujeres adolescentes embarazadas y no embarazadas en Medellín (Colombia) 2009: Estudio de corte transversal. Revista colombiana de obstetricia y ginecología, 2010, 61(3): 207-213.

[35] de Medellín A. Diagnostico situacional de la infancia y adolescencia en el municipio de Medellín. Medellín: Alcaldía de Medellín, 2012.

[36] Viguer P. Nivel socioeconómico y calidad del entorno familiar en la infancia. Anales de Psicología, 1996, 12(2), 197-205.

[37] Estupiñán-Aponte. Aspectos Sicosociales en universitarias embarazadas. Rev de Salud Pública. 2009; 11: 988-998.

[38] Organización Panamericana de Salud (OPS-2007).

[39] Estadística DANE. Proyecciones nacionales y departamentales de población; 2005, 2010, 2020.

[40] Motta F. Protección de la madre gestante y en etapa de lactancia en Colombia. Revista Republicana. 2010; 8: 127-140.

[41] Objetivo del desarrollo del milenio. Mejorar la salud sexual y reproductiva. 5. 2010.

[42] de Salud M, Rica C. Indicadores básicos de salud. Ministerio de Salud: Costa Rica. Recuperado de http://www. ministeriodesalud. go. cr, 2011.

[43] Cabrera J. Cruz G.Cabrera C. Características del peso, edad gestacional y tipo de parto de recién nacidos en el sistema público y privado. Rev Chil Obstet Ginecol 2006; 71(2): 9297.

[44] Betancur Quintero I C, González Trujillo D, Ramos Y P R. Estrategias para la reducción del sobrepeso y la obesidad en los niños, 2016.
[45] Segura O. Fracasaron la consejería preconcepcional y el control prenatal?, una mirada desde las estadísticas vitales en Bogotá (Colombia); 2011; 13: 136-142.

[46] Alonso R, Campo A, Gonzales A. Embarazo en la adolescencia: algunos factores biopsicosociales. Rev. Cubana Med Gen Integr 2005; 21 (5-6).

[47] Martínez L, Valladares M. Análisis de los casos con rotura prematura de membranas y menos de 34 semanas. Rev Cubana ObstetGinecol 1998; 24(3): 145-50.

[48] Delgado M, Gómez M. Comparación de dos índices de asistencia a la atención prenatal y riesgo de parto pretérmino. Gaceta sanitaria.1997; Vol 1, No 3.

[49] Regueira J. Rodriguez R. Comportamiento del riesgo preconcepcional, Rev Cubana Med Gen Integr. 1998; 14(2): 160-4.

[50] Smilkstein G. The family APGAR: a proposal for a family function test and its use by physicians. J FamPract 1978; 6: 1231-9.

[51] Bellón J, Delgado A, Luna J, Lardelli P. Validez y fiabilidad del cuestionario de función familiar Apgar-familiar. Atención Primaria 1996; 18 (6): 289-295.

[52] Pérez-Toga G. Impacto del control prenatal en la morbilidad y mortalidad neonatal. Rev Med Inst Mex Seguro Soc, 2005, 43(5): 377-80.

[53] Huiza L, Pacora P. La muerte fetal y la muerte neonatal tienen origen multifactorial. Universidad Nacional Mayor de San Marcos. 2003; Vol.64, No 1.P. 13-20.

[54] Carrascosa A, Yeste D, Copil A, et al. Patrones antropométricos de los recién nacidos pretérmino ya término (24-42 semanas de edad gestacional) en el Hospital Materno-Infantil Vall d'Hebron (Barcelona)(1997-2002)//Anales de Pediatría. Elsevier Doyma, 2004, 60(5): 406-416.

[55] Yutang J. Complicaciones Perinatales y Vía de Parto en Recién Nacidos de Madres Adolescentes Tempranas y Tardías. 2000; Vol. 61. No 1.P. 46-50.

[56] Bender E, Núñez R. Consumo calórico, estado nutricional materno y retraso del crecimiento intrauterino. Rio de Janeiro Cad. Saúde Pública. 2003; 19(1): 279-285.

[57] Lira J, Oviedo $\mathrm{H}$. Implicaciones perinatales del embarazo en la mujer adolescente. Federación Mexicana de ginecología y obstetricia. Ginecol Obstet Mex. 2005; 73: 407-14.

[58] Nolazco M L, Rodríguez L Y. Morbilidad materna en gestantes adolescentes[J]. Revista de Posgrado de la VIa Cátedra de Medicina, 2006, 156: 13-18.

[59] Villar J, Carroli G, Khan-Neelofur D, et al. Patrones de control prenatal de rutina para embarazos de bajo riesgo. Base de Datos Cochrane de Revisiones Sistemáticas, 2007, 4.

[60] Rivera R. Caba F. Fisiopatología de la rotura prematura de las membranas ovulares en embarazos de pretérmino. Rev Chil Obst Ginecol 2004; 69 (3): 249-255.

[61] Blanco D, Arrieta M. Embarazo y adolescencia. Comportamiento clínico-epidemiológico en el Policlínico Parraga. Revista Habanera de Ciencias Médicas 2010; 9(2) 246-253.

[62] Salinas H, Carmona S. Se puede reducir el índice de cesárea. RevChilObstGinecol 2004; 69 (1): 8-13.

[63] Arandia Valdez R, Ayala Balderrama M. RECIÉN NACIDO" PREMATURO TARDÍO" FRENTE A LOS RIESGOS QUE DEBEN TENERSE EN CUENTA[J]. Gaceta Médica Boliviana, 2010, 33(2): 64-69.

[64] Vergara G. Protocolo parto pretérmino. Colombia: ESE Clínica Maternidad Rafael Calvo, 2009.

[65] Altabhe F. Carroli G. El parto pretérmino: detección de riesgos y tratamientos preventivos. RevPanam Salud Pública. 1999; 5: 373-385.

[66] ARANGO M D E L P, AROCA GONZÁLEZ A N A, CAICEDO PASTRANA C L, et al. Factores de riesgo para parto pretérmino en el departamento de Caldas entre 2003-2006. Archivos de Medicina (Col), 2008, 8(1).

[67] Stella L. Los determinantes sociales de la salud: más allá de los factores de riesgo. Rev. Bogotá, Colombia. Gerenc. Polit. Salud, 2009; 8 (17): 69-79.

[68] Colmenares C C, Schmalbach J E. Salud de la población desde la perspectiva de los determinantes sociales en salud. Revista Salud Bosque, 2015, 3(1): 75-80.

[69] Velasco S, Lopez B. Evaluación de una intervención biopsicosocial para el malestar de las mujeres en atención primaria. Feminismo/s. 2007; pp. 111-131. 
[70] Rangel J L, Valerio L, Patiño J, et al. Funcionalidad familiar en la adolescente embarazada. Rev Fac Med UNAM, 2004, 47(1): 24-27.

[71] Hernández J. Selección del tamaño de muestra de estudios clínicos, rincón epidemiológico, Rev. Col gastroenterología, 2006; 21(2): 118-121.
[72] Madrid S. Paternidades Adolescentes y ordenamiento de género en Chile. Santiago de Chile 2005: versión preliminar, sin publicar. 2005

[73] Alfredo J, Arteaga L. El estrés en adolescentes. UAM, México DF, 2005. 